\title{
A Study on Teaching Business Communication/English in Indian Classroom
}

\author{
Devimeenakshi. K. ${ }^{1} \&$ Sarika Tyagi ${ }^{1}$ \\ ${ }^{1}$ English Division, VIT University, Vellore, Tamil Nadu, India \\ Correspondence: Devimeenakshi. K., M.A., M.Phil. (Ph.D), Asst. Professor, School of Social Sciences and \\ Languages, English Division, VIT University, Vellore, 632104, Tamil Nadu, India. E-mail: \\ devimeenakshik@vit.ac.in
}

Received: March 24, 2013 Accepted: May 7, 2013 Online Published: May 8, 2013

doi:10.5539/elt.v6n6p137 URL: http://dx.doi.org/10.5539/elt.v6n6p137

\begin{abstract}
The aim of this article is to discuss on teaching Business Communication in classroom to Business Administration degree programme students. Indeed, teaching Business Communication in classroom was different experience when compared with Technical English for B.Tech students. The syllabus for Business Communication (English) was also peculiar whereas Business Communication taught in other institutions. Usually in Business Communication we will have components of letter writing (Business letters), writing memos, agendas, circulars, advertisements, Business report writing and Business vocabulary, but in our university we had even Linguistic elements in syllabus such as Phonetics, Word stress, and Sentence stress. In addition to, other portions are Linguistic communication? Barriers to communication, Dyadic communication, Idioms and Phrases, Proverbs, Listening skills, Movie talk and Reading skills. The only thing what any one can find on students with this type of curriculum is that they cultivated more interest to read theory part (Linguistic communication, Barriers to communication, Dyadic communication) than technical matters (Phonetics, Word stress, Sentence stress). Yet they enjoyed Phonemic symbols while spelling their sounds. Perhaps the result point of view allowed them to be inspired with theory content rather than linguistics. Hence, might be learners earned enough experience in having command over English language. Concerned with learning materials it was difficult to search for Linguistic communication. The students felt happy with the academic syllabus due to teaching methodology than the given syllabus. The adopted teaching methodology was communicative language teaching with usual lecturing method. Lecture was lectured with the help of the technical tool power point presentation. The downloaded materials with pictures (power point lessons with pictures) attracted young minds. It is wonder that Business administration students reading Linguistic aspects and sitting for final written exam. Therefore, this paper exposes teaching-learning process of the teacher and student in teaching Business Communication to them.
\end{abstract}

Keywords: business English teaching (BET), business communication (BC) \& business English (BE), laboratory sessions for BE, teaching-learning process, feedback, necessity of English language (need of the hour)

\section{Introduction}

"Silence can speak and so can the eyes, but nothing substitutes the enunciation of thoughts and emotions with words". (Oscar Salomon Cisneros, Modern Day Proverbs, 2010-11)

Communication is noteworthy in current world. Either verbal communication or non-verbal communication should be used to communicate with people. Non-verbal communication can replace verbal communication. But in above quote, verbal communication, specifically verbal accents can't be replaced by silent communication, non-verbal communication through actions. In my perspective, the two types of communication are equally important to enjoy an effective communication. Consequently, it is essential to define communication and business communication thereby knowing the difference between these two. To define communication it is a two way process, sending and replying, just exchanging ideas and sharing information between sender and receiver. According to Scott, Business communication means, "administrative communication is a process which involves the transmission and accurate replication of ideas ensured by feedback for the purpose of eliciting actions which will accomplish organizational goals" (R. C. Bhatia, p. 3) 
Berlo's SMCR model of communication (2008-13) will be suitable to display the process of communication and how it is linked and conveyed. This style "presumes enormous background of behavioural science. This model illustrates the four basic concepts-(1) Sources, (2) Messages, (3) Channels and (4) Receivers. All these concepts are interrelated". (R. C. Batia, 2009, p. 134)

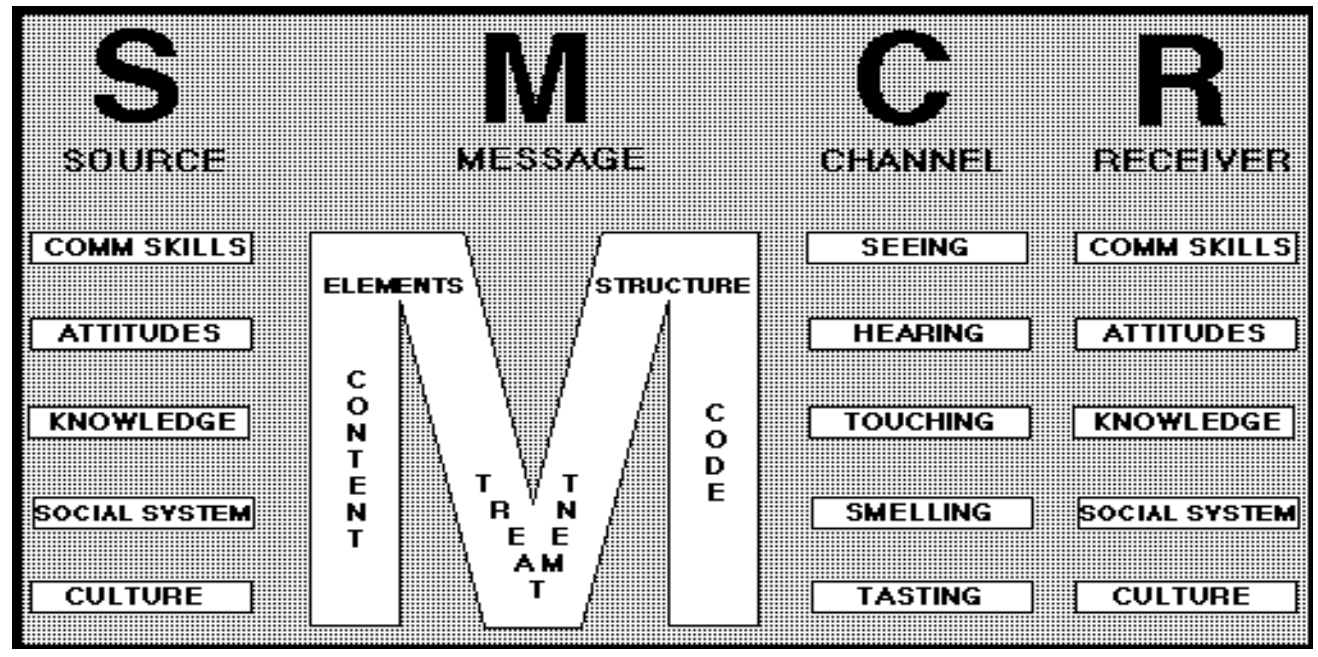

Figure 1. Model of communication - Berlo's SMCR model of communication

The above model exemplifies the communication process, how the encoder sends and decoder receives the message. The source constitutes the essence of the information. The message contains the body of the communication. The channel acts as a catalyst and receiver decodes in producing feedback. The communication process leads to good communication and bad communication. Good communication relies on the effective communication of the communicator. Bad communication leads to break down of communication. Accordingly the picture elaborates the method of communication and how communication should be conveyed through its components. This article deals with Business communication and English language acting as a device to maintain business connection in corporate world. Hence Business communication has become a subject to be taught in schools, colleges and universities to enhance its significance, by this means, using it in improving economic status of any nation.

Usually Business communication encompasses 1. Business letters. 2. Conducting of meetings, 3. Agendas in meetings, 4. Minutes of meetings, 5. Project proposal, 6. Project report, and theory portion of communication like, Barriers to communication, Face-to-face communication and so on. Whereas, the definition of Business English deals with the components of English and they follow:

i. Discourse

1. Word building (Prefixes\&Suffixes)

2. Synonyms \& Antonyms

3. Parts Of Speech

4. Idioms \& Phrases

5. Proverbs

6. Tenses

7. Common Errors

8. Reading comprehension (reading for pleasure)

9. Listening dialogues $\&$ passages (lab session)

10. Pronunciation (lab session), one minute talk \& speeches of great men(L\&S), consonants, vowels, diphthongs, phonemic words, word stress and sentence stress

11. Extempore (activity) \& prepared speech 
ii. Soft skills
1. Interviews (theory)
2. Presentations (theory, seminar?)

iii English language training activity

1. Movie Talk (projected an English movie and asked the students to write/speak on the movie (review). Example - Movie Review

The items from 1-11 will fall under the term, Discourse. Certainly Widdowson's discourse but his ideas were modified (misquoted) by Beugrande in his work. In Beugrande's interpretation of Widdowson's (2000) paper on Discourse, he mentioned Discourse as mini corpus. Besides, he says, "when I queried the key-word collocation 'applied linguistics' and identified Widdowson's prescriptions: 3 ,

1. being concerned with language problems as experienced in the real world (3);

2. taking cognisance [of] the contextual conditions that have to be met in the classroom for language to be a reality for the learners (7);

3. pedagogically treating descriptive findings to make them appropriate as prescription (9);

4. mediation [and] interpretation [to make] relevant the ideas and findings from linguistics (5);

5. mediating between linguistics and other discourses and identifying where they might relevantly interrelate (23);

6. relating and reconciling different representations of reality (5);

7. making people more socio-politically aware of the way language is used to manipulate them (9)",

(Interpreting the Discourse of H.G. Widdowson: A Corpus-Based Critical Discourse Analysis, 2001)

The first point of Beugrande identifies language problems of business administration students to study language in the real world, 2. language as a reality (ideal subject) to them, 3. In descriptive lessons (theory part) allowing them to find out the core idea and interpret in class, 4. Linguistics, the study of language, in this context, students' study language in two forms, spoken and written, they mediate through texts and infer their ideas, 5. In the fifth point (above), the idea is simplified with respect to students' ability. Linguistics and other discourses as spoken, written, structure, grammar and vocabulary, are meant to be learnt and so learners intervene and interlink to understand better. 6 . In the next point, my connotation is to relate and reconcile day-to-day life experiences, formal and informal to suit the purpose. The last point states how students apply language in society as corporate men. The other two aspects are Soft skills and English language activity. Here, the teacher's role is as a trainer/facilitator, learners roles are destined to be as trainees and it is necessary for them (trainees) to be skilled at these talents.

Substantiating that discourse consisting of structure, grammar, vocabulary and pragmatics-socio-cultural competence with the aid of Moron, Cruz, Amaya, and Lopez pragmatic knowledge that it "involves knowing how words and utterances can be assigned specific meanings in context and function as the vehicles of their users' intentions (2009, pg.13) in terms of socio-cultural competence. For example a sender out of obligation uses polite expressions to persuade the receiver. Particularly in spoken form, "the ability to produce utterances that are appropriate to the sociocultural context in which communication takes place, i.e. to the social contextual factors such as participants' age, gender, power or distance; stylistic factors such as politeness conventions and strategies, degrees of formality or field-specific registers; cultural factors such as awareness of dialect or regional differences in the target language, differences and similarities in terms of usage of communicative strategies between the L1 and the L2, social and institutional structure of the target culture, etc". (Moron, Cruz, Amaya, and Lopez, 2009, p. 14). These practices include three skills such as listening, speaking, and reading, despite the facts L1 and L2, here, since the students are business administration students. How ever, the concept can be taken into reality to learn English language, whereas language is subject to learners. The pragmatic knowledge deals with spoken and written forms simultaneously listening form too. What ever we do either reading or writing we listen to mind and work hence the above said three skills constitute pragmatics-socio-cultural competence.

\section{Business English Teaching}

The assigned syllabus is divided into three parts, 1. Discourse, 2. Soft skills, 3. English language training activity. The first seven items (word building - common errors) were taught by chalk-talk method. The students were assigned to work on assignments, like, submitting worksheets on grammar exercises or doing exercises in class 
as classwork. It would be worth to mention one example, pupils submitted assignments on Parts of Speech, they should download questions/quizzes through online and must write answers. ESL, IELTS exercises or any competitive exam model quizzes also they can work on and excel. The work is evaluated in terms of their hard work consequently to carry out these exercises. Merited candidates score highest grade. In classroom exercises I would engage them with downloaded questions or might give self questions to assess their skill in doing/completing exercises fast. The other four items from the list (12-15) were also classroom exercises. Reading comprehension is meant as reading for pleasure. Some stories would be displayed (teaching tool-power point presentation) and were recommended to read them to develop their vocabulary skills thereby improving their English language through new words and themes. Such practices supplement pleasure to them. The question pattern was multiple-choice question hence they gained the capacity of skimming and scanning the given story or passage in order to choose answers to given questions. In listening sessions, learners listened to speeches of great leaders and BBC learning activity passages as well as dialogues to identify words and meanings of listening exercises. They were trained and advised to follow native speaker's accents. Our students are recommended to ensue British accents, we, as Indians are familiar with British accents than recent American accents. While teaching consonants, vowels, diphthongs, phonemic words, word stress and sentence stress, I portray the lessons and utter the words simultaneously allowing them to spell words. In stress lessons, they have to find out the stress in word and sentence, if they go wrong, I teach them or show them the answers. The students were instructed to be skilled in oral presentation which could enhance their spoken skills.

The next part was Soft skills, materials on interviews and presentations were exhibited and explained, even through class lectures were also delivered and highly recommended to preserve the material so as to brush up their memories when ever necessary. The last part was English language training activity, some scenes of movie were projected and questioned to write and speak on them, like review.

\section{Business Communication and Business English}

Business communication involves

1. "growth in size of organizations (having more contacts abroad)

2. growth of trade unions (effective communication to maintain meaningful relation between management and workers)

3. growing importance of human relations(workers are humans, management should be generous enough to understand the issues of workers and maintain good relationship)

4. public relations (customers, government, suppliers and the public at large)

5. advances in behavioural sciences (developing positive attitude towards life and building up meaningful relationships)

6. technological advancements (advancements must lead to proper communication between superiors and subordinates becomes very necessary)

7. motivation and morale (inspiring people to work hard, fostering positive attitudes, managers can increase the self-confidence and job satisfaction of employees by keeping in close touch with them)

8. Corporate image (creating goodwill in society)"

(R.C.Bhatia, 2009, p.4)

Business English involves components of English language so why Business communication is incorporated with Business English? It is just communication, indeed it is proud to say that pupils who are specialized in English language, that to exactly English language communication, which is termed as communication skills, now, especially by Multi-National company officials who come for placement services to recruit such candidates in India. Thus, English language is highlighted and equalized with computer language, obviously stating placement services people need two languages, computer language and English language.

Communication is processed only by language. People use language as a tool and communicate with tradesmen to have business with them. Since business deals with money no wonder Business communication is celebrated only with English language. Communication and language are inseparable and inevitable. Their roles are essential in world market. Students are taught to work in any industry in future. Moreover nowadays learners must be guided accurately in order to sustain their position in any company at least for five years. Without skill it is difficult for the survival of professionals to stick in one firm. Thus educational institutions are giving importance to English language due to communication skills. It is really happy to note that some Government colleges have renewed English department after a few years. The credit goes to growing multi-national 
companies in India. The officials recruit students with high command of English language seeking standard English in two forms of communication, spoken and written. They expect the ideal presentations of students that can help their growth in various issues.

\section{Laboratory Sessions for BE}

Listening, speaking and writing skills (lessons - i. pronunciation (vowels, consonants, diphthongs, phonemic words, and stress, ii. Listening to speeches, passages and dialogues, iii. Vocabulary) can be taught through English language laboratory classes. Afterwards as per given syllabus, the implied methodology was i. using technology in classroom, subsequently used LCD projector and speakers to edify students. If students had been taught through English language multi-media software, they would have learned easily. More over the classes would have been more effective than the method that was employed in classroom to students. Every one would be given a separate system to work on along with an individual head phone, as a result, more scopes to learn better and appreciate English language through visions, accents of native speakers, and exercises resembling games. Laboratory classes would inspire a lot. But my given scheme was classroom sessions hence no other go I should teach them in classroom than in English language laboratory. Particularly, listening and speaking skills must be trained only through English language multi media software (Hi-class software) to have an effective class.

\section{Teaching-Learning Process}

\subsection{Roles and Functions of Teacher}

\subsubsection{Roles}

The tutor takes different roles, "diagnostician, planner, manager and provider" (Parrott, 2010, p. 94) in teaching-learning process. At the primary level let us see how a teacher acts as a diagnostician? She/he plays the role of diagnostician while diagnosing the learner. It is like communication process how a sender (trainer) sends the information and how the receiver (trainee) receives the message. The sender will psychologically analyse the receiver and continue the work. Perhaps the receiver knew or not whether the sender is examining him, the process will happen. Later as a manager, the duty is to tackle classroom classes and to develop her/him as an efficient instructor to satisfy the needs of students. In addition to, she/he has to respond to the feedback of students. It is better to analyse the genuine feedback of students perhaps to understand them. As a provider the sender will circulate resources and enlighten them. The training materials of trainer (input) guarantee the received knowledge of recipients (trainees). The output of received skills of learners assures the outcome of learning in teaching-learning process.

\subsubsection{Function}

- "To find out (as far and as consistently as possible) the needs, interests, language difficulties and preferred learning styles of the students.

- To cater for these (as far as group exigencies allow).

- To foster a group feeling (cooperation, liking, common aims, mutual confidence, etc.).

- To ensure that learners have clear short and long-term learning aims.

- To assess the progress of individuals and of the class as a whole.

- To ensure the learners are aware of this progress.

- To encourage students to take responsibility for their learning.

- To vary patterns of interaction within the lesson according to the precise plans and nature/feeling of the group.

- To ensure that the students find their involvement sufficiently challenging.

- To analyse and present realistic 'chunks' of the target language for students to process.

- To select and introduce activities and materials for language work.

- To help students develop positive, individual strategies for learning". (Parrott, 2010, p. 94)

Therefore, the trainer is clearly acting as a diagnostician, planner, manager and provider according situational environment and situation in performing these functions appropriately and respectively. Sometimes it appears to be a confront between the trainer and trainee. 
Table 1. Result of Teaching-learning process

\begin{tabular}{lllllll}
\hline S.No & Assessment & Subject & $\begin{array}{l}\text { Class } \\
\text { Average(65) }\end{array}$ & $\begin{array}{l}\text { No } \\
\text { students }>=\mathbf{2 5}\end{array}$ & \% of pass & Feedback \\
\hline 1. & Cat-1(50) & G,D & 27.21 & 59 & 90.77 & Better \\
\hline 2. & Cat-2(50) & G,P1,D & 29.07 & 54 & 83.08 & Should improve \\
\hline 3. & Quiz-1(5) & C.Q & 3.66 & 57 & 87.69 & Good \\
\hline 4. & Quiz-2(5) & RS \& A & 3.17 & 51 & 78.46 & Better \\
\hline 5. & Quiz-3(5) & G & 3.12 & 47 & 72.31 & Should improve \\
\hline 6. & Assignment(5) & IP \& P2 & 3.82 & 60 & 92.31 & Good \\
\hline 7. & Consolidate(50) & ALL & 30.59 & 58 & 89.23 & Good \\
\hline
\end{tabular}

Cat (50 marks)-continuous assessment test, G-grammar, D - descriptive type (essay and paragraph writing), P1 - phonology, Quiz (5 marks)-C.Q - Comprehension questions, RS \& A - Reading story and answering, Assignment (5 marks)-IP - idiomatic phrases, P2 - proverbs, All - all subjects together. Please note: Other topics in curriculum are done as class work exercises. Class average - total number of students in a class is 65 , class average of total students. No. of students $>=25$ - total number of students scored pass mark and fail mark, $>25=$ failed candidates, 25 and above $=$ passed candidates. $\%$ of pass - pass percentage and feedback

The evaluation type is normal paper correcting practice, deleting marks for wrong spellings, grammatical errors and irrelevant information. The main aim of assessing the answer script is to mould the student and help him/her to get better score in final exam. The continuous assessment marks, quiz marks and assignment marks are statistically analysed respectively to ensure the final results of students. These tests reveal their efficiency in studying the syllabus-based topics and other reference works based on the subject and presenting their ideas in examination point of view. The continuous assessment tests, quizzes and assignment, these various types of assessment marks may stand for pre-test marks and consolidation marks may stand for post-test assessment (all subjects together). The improvement in every phase and lastly how they score in the course of development proves the net result of students.

\section{Feedback}

"Like success, failure is many things to many people. With Positive Mental Attitude, failure is a learning experience, a rung on the ladder, a plateau at which to get your thoughts in order and prepare to try again".

(W. Clement Stone, 2011-13)

Similar to the said quote, if you get a negative feedback, you may think and act. Initially, find out whether the feedback is the precise feedback. Common errors are simpler to rectify. Tolerance from both sides (encoder and decoder) are highly valued. Negative remarks are strengthened by converting them into positive factors by one's attitude. Failure is a learning experience, learn, climb up the ladder to achieve the goal. No one can get rid of feedback indeed it is an important facet in every teaching-learning process. A positive response will threaten you to proceed further, sustaining the position is difficult. Changing roles may well bring good prospects. At last, forbearance towards English language is compulsory to give feedback from two ways (sender and receiver).

\section{Necessity of English Language to All Disciplines}

1. Proficiency in language is fundamental to all disciplines so to master any core subject.

2. The two forms of communication viz. spoken and written predominant the industry world.

3. Presentations (oral \& written) captivate audience to plan for action.

4. Soft skills are brought to light especially with the aid of English language.

5. Corporate world needs linguists and communication skills' experts to develop monetary wealth globally.

6. In current scenario, English is dire need to the needy of English language in society. It is the elixir of professional life.

\section{Conclusion}

Nowadays business communication is interlinked with business English as we all know that world has become global village. Any literate in the world who knew English could communicate to the other person in any part of 
the world. In business communication it is the only tool to do transactions and conducting meetings/conferences. It is impossible to have any business activity without communication. This proposed thought has become a motto in this materialistic world. Hence to be experts in business communication along with other subjects students select business administration course. Compulsorily they have to clear two papers or one paper in Business Communication. Through business communication they learn how to negotiate, how to have dealings with dealers, how to build relationship with people and ultimately to develop positive approach then to use polite expressions. It was an opportunity for me to take the subject with more components of English language. Since the subject is dominated with more elements of English language it can be called as Business English than Business Communication. Really, a valuable point is to be added at this moment, that a subject (business communication) belonging to other department (business school) is been asked to handle by an English teacher (i.e) a language teacher to teach a subject as it has the components of English language. The tri-parts, Discourse, Soft skills and English language activity were powerful and useful to learners only through teaching and learning materials. The valid feedback from the students was liking. They showed interest to learn English language as a subject. Even more improvements too can be done for Business English Teaching by further methods.

\section{Recommendations}

1. First, the title Business English can be better than Business Communication because the very title misguides people. Business English consists of four skills, listening, speaking, reading and writing whereas Business Communication most probably deals just with written forms (business correspondences)

2. Second, English laboratory sessions would be good for students to learn phonetics and to listen to speeches and passages while having lessons in theory classes since Business Communication is a subject.

3. Third, every skill individually (communication skills) would have been in an order as English language syllabus than the subject syllabus so that to concentrate on each skill and to manage time.

4. Fourth, the hierarchy might provide the background study of communication skills to students. For example, if listening skills are taught first, they can learn that it is the key skill to be learnt first followed by rest of the skills.

\section{References}

Berlo's SMCR model of communication. (2008-13). Retrieved March 23, 2013, from http://www.managementstudyguide.com/berlo-model-of-communication.htm

Beugrande. (2001). Interpreting the Discourse of H.G. Widdowson: A Corpus-Based Critical Discourse Analysis, Retrieved February 18, 2013, from http://www.beaugrande.com/WiddowsonianDiscourse.htm

R. C. Bhatia. (2009). Business Communication (p. 4). New Delhi, Ane Books PVT. Ltd.

Burkill, Bob, Eaton, \& Ray. (2011). Developing Teaching and Learning. New Delhi. Cambridge University Press.

Cisneros, Oscar Salomon. (2010-11). Modern Day proverbs. Retrieved March 20, 2013, from http://emote.net/modern_day_proverbs.html

Meenakshi Raman, \& Prakash Singh. (2006). Business Communication. New Delhi, Oxford University Press.

Moron, Cruz, Amaya, \& Lopez. (2009). Pragmatics Applied to Language Teaching and Learning. Retrieved March 20, 2013, from http://www.c-s-p.org/Flyers/978-1-4438-0972-6-sample.pdf

Parrott, Martin. (2010). Task for Language Teachers (p. 94). Cambridge. Cambridge University Press.

Stone W. Clement. (2011-13). Proverbs on communication and relationships. Retrieved March 17, 2013, from http://www.brainyquote.com/quotes/keywords/learning.html 
Appendix 1. Syllabus copy

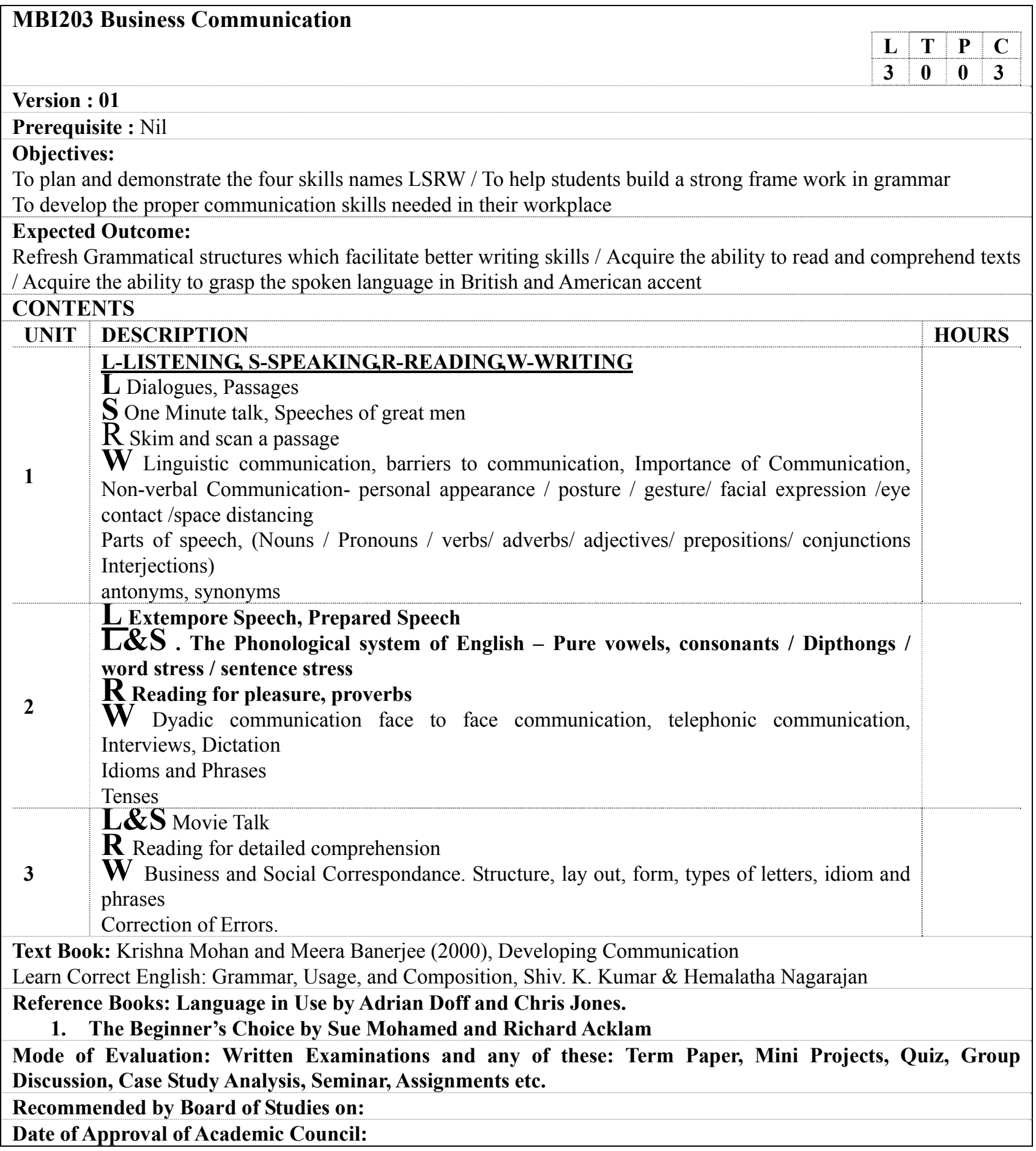




\section{Appendix 2.}

\begin{tabular}{|c|c|c|c|c|c|c|}
\hline S.No & Assessment & Subject & $\begin{array}{l}\text { Class } \\
\text { Average } \\
\end{array}$ & $\begin{array}{lr}\text { Nor of } \\
\text { students }>=25 \\
\end{array}$ & $\begin{array}{l}\% \text { of } \\
\text { pass }\end{array}$ & Feedback \\
\hline 1 & $\begin{array}{l}\text { CAT } 1 \\
(50 \text { marks })\end{array}$ & 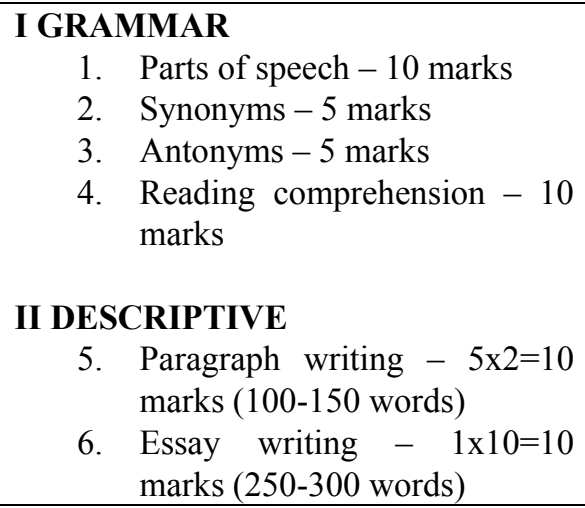 & 27.21 & 59 & 90.77 & Better \\
\hline 2 & $\begin{array}{l}\text { CAT } 2 \\
\text { (50 Marks) }\end{array}$ & $\begin{array}{l}\text { I GRAMMAR\&PHONOLOGY } \\
\text { 1. Tenses - } 10 \text { marks } \\
\text { 2. } \\
\text { Reading comprehension } \\
\text { (questions based on idioms \& } \\
\text { phrases, proverbs) }-10 \text { marks } \\
\text { 3. Transcript }-10 \text { marks } \\
\text { II Descriptive } \\
\text { 4. Paragraph writing }-5 \times 2=10 \\
\text { marks (100-150 words) } \\
\text { 5. } \begin{array}{l}\text { Essay writing }-1 \times 10=10 \\
\text { marks (250-300 words) }\end{array}\end{array}$ & 29.07 & 54 & 83.08 & $\begin{array}{l}\text { Should } \\
\text { improve }\end{array}$ \\
\hline 3 & $\begin{array}{l}\text { Quiz } 1 \\
\text { (5 marks) }\end{array}$ & Comprehension questions & 3.66 & 57 & 87.69 & Good \\
\hline 4 & $\begin{array}{l}\text { Quiz } 2 \\
\text { (5 marks) }\end{array}$ & $\begin{array}{l}\text { Reading the story and answering } \\
\text { (reading for pleasure) }\end{array}$ & 3.17 & 51 & 78.46 & Better \\
\hline 5 & $\begin{array}{l}\text { Quiz } 3 \\
\text { (5 marks) }\end{array}$ & Grammar - correcting the errors & 3.12 & 47 & 72.31 & $\begin{array}{l}\text { Should } \\
\text { improve }\end{array}$ \\
\hline 6 & $\begin{array}{l}\text { Assignment } \\
(5 \text { marks })\end{array}$ & $\begin{array}{l}\text { Assignments on Idiomatic phrases and } \\
\text { Proverbs }\end{array}$ & 3.82 & 60 & 92.31 & Good \\
\hline 7 & 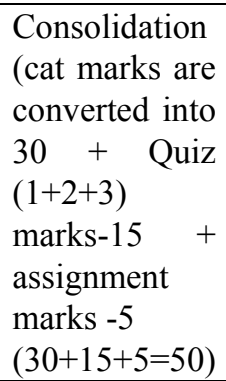 & All subjects together & 30.59 & 58 & 89.23 & Good \\
\hline
\end{tabular}




\section{Chart 1.}

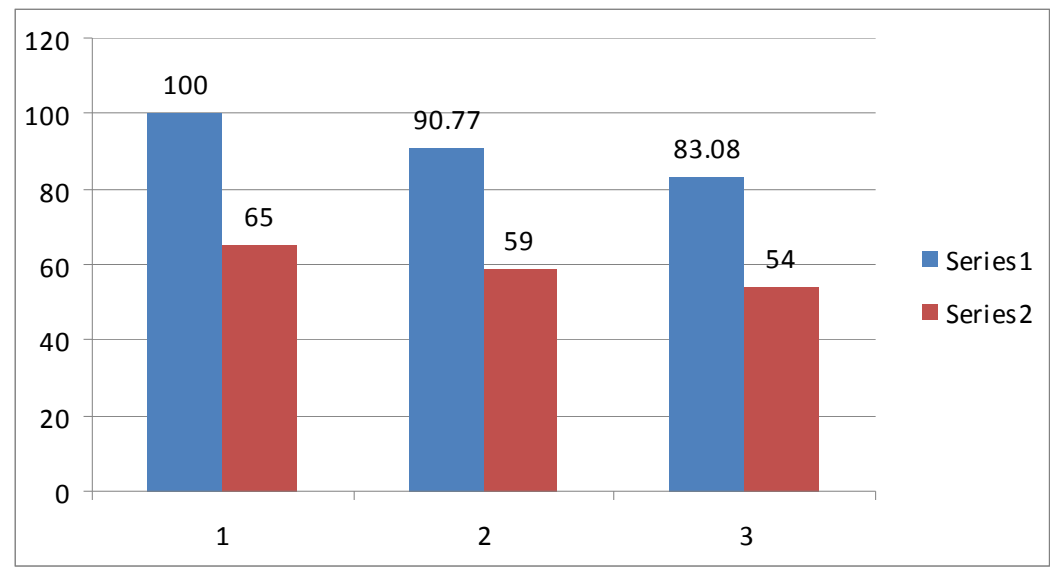

Total percentage $-100 \%$, total strength of students -65

Cat $-1 \%-90.77 \%$, class average -59 , Cat $-2-83.08 \%$, class average -54

\section{Chart 2.}

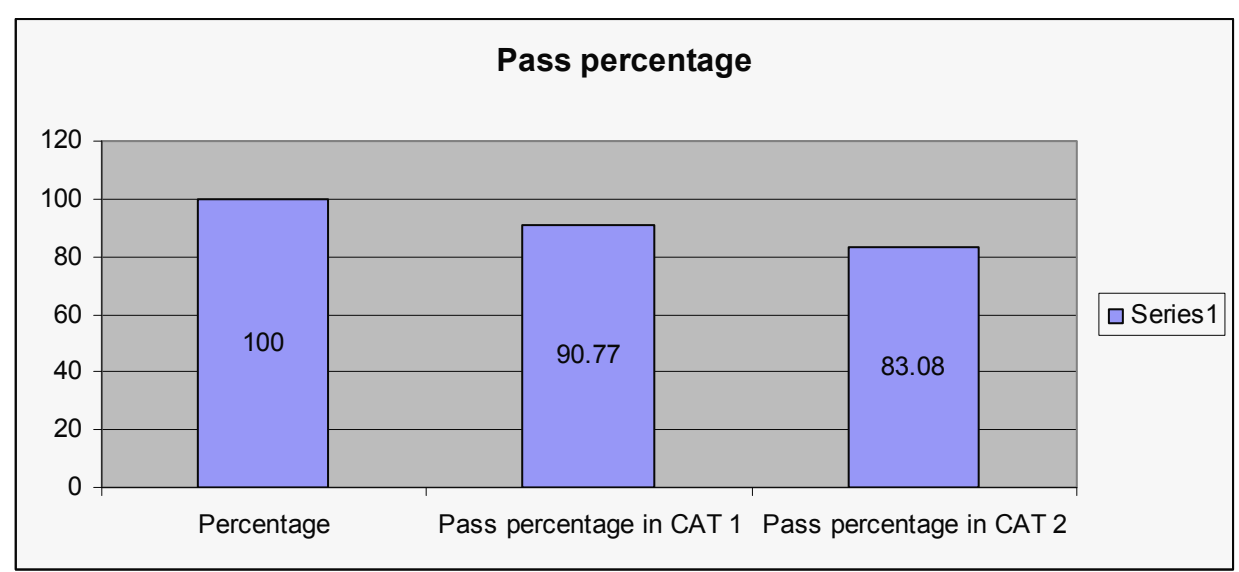

Chart 3.

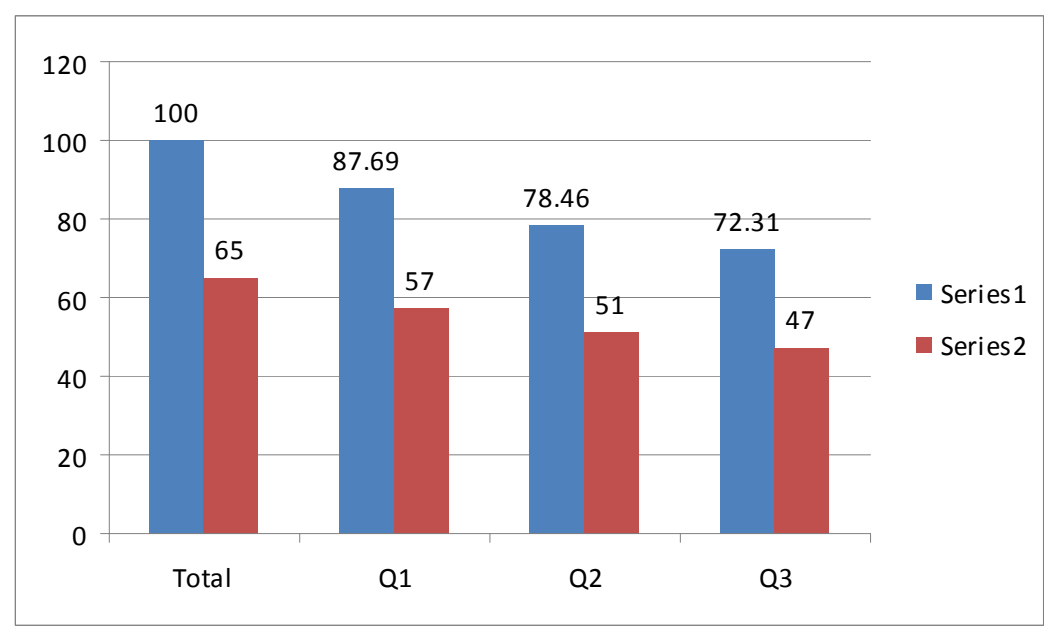

Total percentage (100\%) and total number of students (65), Quiz-1, 2, \&3 pass percentage and class average 


\section{Chart 4.}

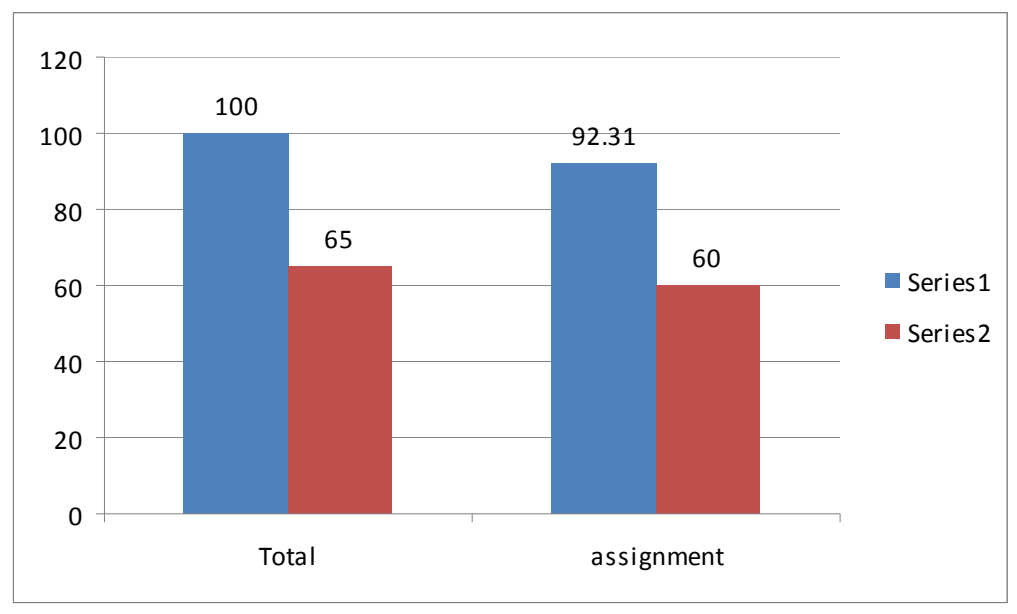

Total percentage $-100 \%$, total number of students -65 , assignment pass percentage and class average

\section{Chart 5.}

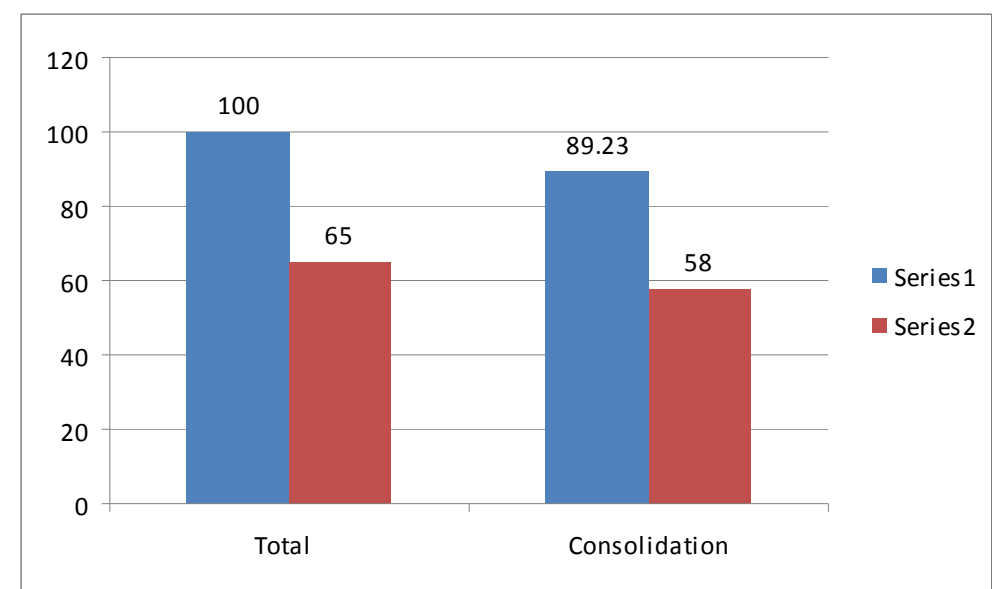

Total percentage $-100 \%$, total number of students -65 , consolidation - pass percentage and class average 